\title{
SH2D1A Gene Mutation
}

National Cancer Institute

\section{Source}

National Cancer Institute. SH2D1A Gene Mutation. NCI Thesaurus. Code C153505.

A change in the nucleotide sequence of the SH2D1A gene. 